\title{
MEMBANGUN NILAI BEHAVIORAL INTENTION MELALUI TOURIST
} EXPERIENCE

\section{(Studi Tentang Tourist Experience Dampaknya Terhadap Behavioral Intention di Floating Market Lembang)}

\author{
Ramdani Setiyariski $^{1}$ Didin Syarifuddin $^{2}$ dan Yuliana Pinaringsih Kristiutami ${ }^{3}$ \\ ${ }^{1,2}$ Sekolah Tinggi Pariwisata ARS Internasional, Indonesia. Email : ramdani.riski@gmail.com \\ ${ }^{3}$ Akademi Pariwisata BSI Bandung, Indonesia.
}

\begin{abstract}
Histori Artikel

Submitted:

11 Maret 2019

Reviewed:

18 April 2019

Accepted:

20 April 2019

Published:

15 Mei 2019

Floating Market Lembang is a destination in Lembang, the boundary of West Bandung. Visitors visit in Floating Market Lembang always increasing in years. But that fact is not the same with the data which say tourist's loyality haven't maximum because majority of the tourist whose come to Floating Market lembang are new visitors. Decision of this research is to know influence of tourist experience to behavioral intention of Floating Market Lembang. The type of research are descriptive and verification. The survey method used is incidental sampling, which a sample size of 120 respondents. Data analysis technique using single regression techniques with coefficient determinant $\left(R^{2}\right)$ and partial $(T)$ techniques. These results shows that there is a significant partial influence tourist experience to behavioral intention of Floating Market Lembang. The higher the ability of destination management in building positive experience on the tourists, so that it will increase positive image of the tourists in their visits. In this condition, directly or indirectly it will be able to build tourist's willing in re-visiting to the destination. The correlation of the two variables can be simplisized in a sentence that in order to be able to build value of behavioral intention is how to be able to build tourist experience.
\end{abstract}

Keywords: Tourist, Tourist Experience, Behavioral Intention

\section{PENDAHULUAN}

Destinasi wisata dengan atraksi wisata merupakan daya tarik utama bagi masyarakat yang berkunjung. Indonesia memiliki berbagai destinasi dan daya tarik wisata yang yang memiliki potensi nilai jual yang tinggi, terutama dalam menarik wisatawan dalam berkunjung dan mengenal beragam daya tarik wisata yang ada di Indonesia (Syarifuddin, 2013). Berbicara destinasi wisata tidak akan lepas dari faktor pendukungnya yaitu fun, food and fashion. Fenomena menambahkan liburan sebagai kebutuhan pokok masyarakat, pesatnya perkembangan industri pariwisata, terjangkaunya biaya liburan oleh seluruh lapisan masyarakat, tingginya tuntutan masyarakat untuk mendapatkan pengalaman baru dari gaya hidup konsumtif, telah menjadi fenomena masyarakat hampir di setiap kota besar (Syarifuddin, 2017).

Ketika kebutuhan fun dijadikan gaya hidup, maka dapat dijadikan peluang baru bagi sebuah kota untuk mendatangkan wisatawan sebanyak-banyaknya, karena akan memberikan devisa yang tinggi bagi kota yang dikunjunginya (Syarifuddin, 2019). Salah satu daerah yang memiliki banyak daya tarik wisata di Indonesia adalah Kabupaten Bandung Barat. Berikut ini adalah jumlah kunjungan wisatawan di Kabupaten Bandung Barat: 
Tabel 1.

Jumlah Kunjungan Wisatawan Mancanegara dan Domestik di Kabupaten Bandung Barat, 2012-2016

\begin{tabular}{ccccc}
\hline \multirow{2}{*}{ Tahun } & \multicolumn{2}{c}{ Wisatawan } & \multirow{2}{*}{ Jumlah } \\
& Mancanegara & Domestik & \\
\hline 2012 & 10.268 & 1.278 .179 & 1.288 .447 \\
2013 & - & - & - \\
2014 & 278.027 & 1.278 .179 & 1.556 .206 \\
2015 & 278.027 & 1.278 .179 & 1.556 .206 \\
2016 & 278.027 & 1.289 .657 & 1.567 .684 \\
\hline
\end{tabular}

Salah satu destinasi pariwisata di Kabupaten Bandung Barat adalah Flating Market Lembang yang terletak di Jalan Grand Hotel No. 33E, Lembang. Floating Market merupakan destinasi wisata yang dibuka pada tahun 2012, namun tingkat kunjungannya, semakin meningkat, karena memiliki tema yang cukup berbeda dengan destinasi wisata lain. Daya tarik yang ditawarkan Floating Market adalah pasar terapung yang digunakan untuk berjualan beragam jenis makanan di tepian danau yang dimanfaatkan dan dikemas untuk aktifitas wisata untuk dapat menarik wisatawan dan memberikan kepuasan terhadap wisatawan.

Selama beberapa periode, berdasarkan catatan pengelola Floating Market Lembang perkembangan jumlah wisatawan kawasan ini terus mengalami peningkatan, dapat dilihat dari tabel kunjungan wisatawan ke Floating Market Lembang berikut ini:

Tabel 2

\section{Jumlah Kunjungan Wisatawan di Floating Market Lembang}

Desember 2012 - 2017

\begin{tabular}{cc}
\hline Tahun & Jumlah Wisatawan \\
\hline $\begin{array}{c}\text { Desember } \\
2012\end{array}$ & 7.923 \\
2013 & 258.413 \\
2014 & 283.359 \\
2015 & 357.045 \\
2016 & 485.578 \\
2017 & 718.641 \\
\hline
\end{tabular}

Berdasarkan Tabel 2, Jumlah wisatawan di Floating Market Lembang terus meningkat tiap tahunnya. Namun hal tersebut belum dapat membuktikan apakah wisatawan yang berkunjung adalah wisatawan yang sudah berkunjung sebelumnya atau wisatawan baru. Untuk mengetahui wisatawan yang berkunjug ke Floating Market Lembang adalah wisatawan baru atau wisatawan yang sudah berkunjung sebelumnya, maka dilakukan pra penelitian dengan menyebar kuesioner kepada 30 pengunjung yang dilakukan pada tanggal 28 Juli 2018. Hasil pra penelitian wisatawan yang berkunjung ke Floating Market Lembang dalam gambar 1 sebagai berikut:

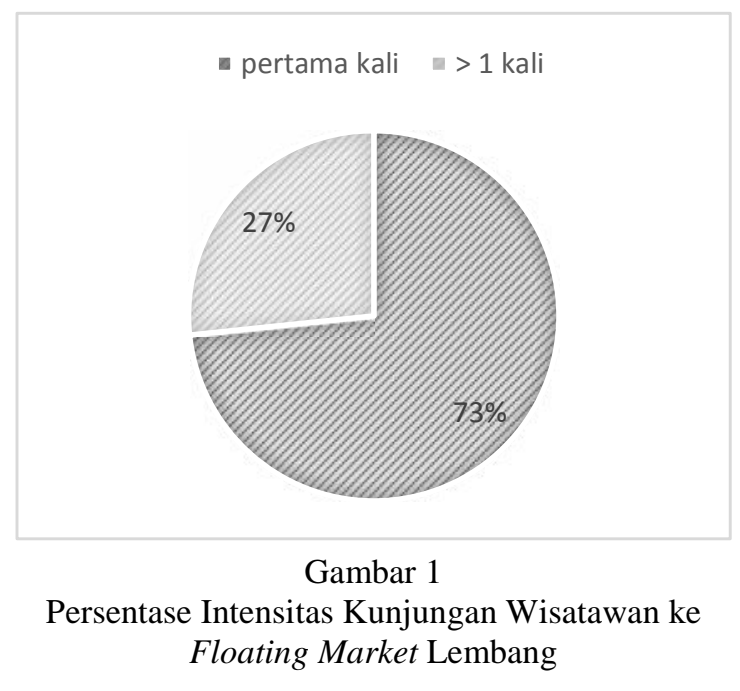

Berdasarkan hasil pra penelitian pada Gambar 1, dapat dilihat bahwa sebesar 73\% wisatawan yang baru pertama kali berkunjung ke Floating Market Lembang dan sisanya sebesar $27 \%$ wisatawan yang sudah lebih dari satu kali berkunjung ke Floating Market Lembang. Hal ini didukung dengan muncul ulasan negatif dari wisatawan terhadap Floating Market Lembang yang disampaikan pada media online.

Ulasan negatif tersebut memperlihatkan adanya kekecewaan wisatawan setelah berkunjung ke Floating Market Lembang diantaranya dengan kurang baiknya kualitas pelayanan yang diberikan oleh Floating Market Lembang. Hal tersebut memungkinkan berpengaruh pada perilaku wisatawan dimasa yang akan datang. Seperti yang diutarakan oleh Lovelock \& Wirtz (2010), kesan negatif terhadap pelayanan 
yang diberikan oleh pengelola daya tarik wisata dapat menjadi WOM negatif (negative word of mouth) bahkan sampai pada ketidakhadiran kembali wisatawan atau wisatawan enggan berkunjung ke tempat ini, artinya loyalitas wisatawan semakin menurun.

Behavioral intention pelanggan sangat penting bagi perusahaan, karena pemahaman niat mereka dari revisit dan word-of-mouth setelah tour mereka dapat membantu meramalkan apakah target pelanggan akan menjadi pelanggan jangka panjang dan membawa lebih banyak keuntungan untuk perusahaan (Shen, Fan, Zhan, \& Zhao, 2014). Hal serupa diungkapkan oleh Chen \& Tsai (2007) yang menyatakan bahwa dengan memahami hubungan antara perilaku dimasa depan dan penentunya, manajer destinasi pariwisata akan lebih mengetahui bagaimana membangun citra yang menarik dan meningkatkan pemasaran untuk menggunakan sumber daya mereka secara maksimal. Ramukumba (2018) menambahkan bahwa peningkatan 5\% kunjungan ulang wisatawan akan meningkatkan 25-85\% pendapatan perusahaan.

Mengacu pada latar belakang yang telah disampaikan, peneliti menganggap perlu untuk melakukan penelitian dengan tema Tourist Experience dan Behavioral Intention dalam judul Membangun Nilai Behavioural Intention melalui Tourist Experience dalam Studi tentang tourist experience dampaknya terhadap behavioral intention di Floating Market Lembang.

\section{LITERATURE REVIEW}

Menurut Rageh, Melewar, \& Woodside (2013) Tourist experience / customer experience adalah respon internal dan subjektif dari konsumen dengan perusahaan, baik kontak secara langsung maupun tidak langsung. Tourist experience merupakan pengalaman yang didapatkan oleh konsumen baik secara langsung maupun tidak langsung mengenai proses pelayanan, perusahaan, fasilitas-fasilitas dan bagaimana cara seorang konsumen berinteraksi dengan perusahaan dan dengan konsumen lainnya yang akan membuat respon kognitif, emosi dan perilaku konsumen dan meningalkan kenangan tentang pengalaman (Walter, Edvardsson, \& Ostrom, 2010). Menurut Stamboulis et al dalam Chang, Backman, \& Huang (2014), tourist experience merupakan pengalaman wisatawan selama perjalanan wisata berkaitan dengan kegiatan mengunjungi, melihat, belajar, dan menikmati gaya hidup yang berbeda.

Menurut Othman, Zahari, \& Radzi (2013), Behavioral intention mengarah pada kemungkinan seorang pelanggan kembali ke perusahaan yang layanannya telah mereka gunakan atau menyebarkan informasi positif tentang suatu organisasi untuk keluarga dan teman-teman. Behavioral intentions didefinisikan sebagai perilaku potensial yang mungkin dipicu oleh kepuasan atas kualitas pelayanan (Kuruuzum \& Koksal, 2010). Dan menurut De Nisco, Mainolfi, Marino, \& Napolitano (2015), behavioral intention merupakan ni

at untuk kembali dan word of mouth yang positif suatu Negara sebagai destinasi wisata dalam hal niat untuk membeli dan word of mouth yang positif terhadap produk nasional.

Hubungan antara Tourist Experience dengan Behaviral intention karena pada dasarnya pengunjung akan memiliki minat berkunjung kembali ataupun merekomendasikan kepada orang lain atas dasar pengalaman positif yang didapatkan dari kunjungan ke destinasi pariwisata. Menurut Hosany dalam Chang et al., (2014) pengalaman berwisata yang positif merupakan factor penentu utama dari perilaku wisatawan pasca perjalanan yang mempengaruhi perilaku masa depan sebagai niat untuk berkunjung kembali. Tang \& Qiu (2015) menyatakan "The perception of this experience has influence on their satisfaction and behavioral intention. As aresult, evaluation about museum, even the whole tourist destination", bahwa persepsi pengalaman ini berpengaruh terhadap kepuasan dan niat perilaku. Hasilnya, evaluasi tentang museum, bahkan seluruh 
destinasi pariwisata. Dan hal ini memperkuat hasil penelitian sebelumnya yang menjelaskan bahwa tourist experience di Gunung Galunggung berada pada kategori tinggi dan behavioral intention berada pada kategori cukup tinggi, behavioral intention dipengaruhi oleh tourist experinece sebesar 47,4\% (Balqis, 2016)

\section{METODE PENELITIAN}

Metode penelitian yang digunakan dalam penelitian ini adalah metode deskriptifverifikatif. Penelitian deskriptif-verifikatif adalah penelitian yang menjelaskan masalah dalam variabel yang diteliti serta menjelaskan hubungan yang bersifat kausalitas dari variabel pengaruh terhadap variabel terpengaruh (Sugiyono, 2014). Penelitian ini bertujuan untuk memperoleh gambaran mengenai touris experience dan behavioral intention di Floating Market Lembang.Populasi pada penelitian ini adalah Pengunjung di Floating Market Lembang. Besarnya sampel yang digunakan dalam penelitian ini adalah sebanyak 120 responden. Penghitungan besar sampel menggunakan rumus Slovin.

\section{HASIL DAN PEMBAHASAN}

\section{Uji Autokorelasi}

Tabel 3

Hasil Uji Autokorelasi

Model Summary ${ }^{\mathrm{b}}$

Model Summary ${ }^{\mathrm{b}}$

Std.

Adjusted
$\mathrm{R}$ the $\begin{gathered}\text { Error of } \\ \text { the Durbin- }\end{gathered}$

Model $\mathrm{R}$ Square Square Estimate Watson

\begin{tabular}{llllll}
\hline 1 &, $762^{\mathrm{a}}$ &, 580 &, 577 & 7,62512 & 2,305
\end{tabular}

a. Predictors: (Constant), Tourist Experience

b. Dependent Variable: Behavioral Intention

Sumber: Output Olah Data Statistik Tahun 2018

Tabel 3, menunjukan hasil uji autokorelasi. Dari tabel tersebut, dapat dilihat bahwa nilai Durbin Watson:

$=\mathrm{dU}<\mathrm{DW}<4-\mathrm{dU}$
$=1,694<2,305<4-1,694$

$=1,694<2,305<2,306$

Dengan demikian, dapat disimpulkan bahwa tidak terdapat autokorelasi pada model ini.

\section{Uji Regresi Liniear Sederhana}

Tabel 4, menunjukan hasil uji regresi linearr sederhana. Model persamaan regresi yang dapat dituliskan dari hasil uji regresi sederhana diatas dalam persamaan regresi bentuk standard adalah sebagai berikut:

Tabel 4

Hasil Uji Koefisien Regresi Linear Sederhana

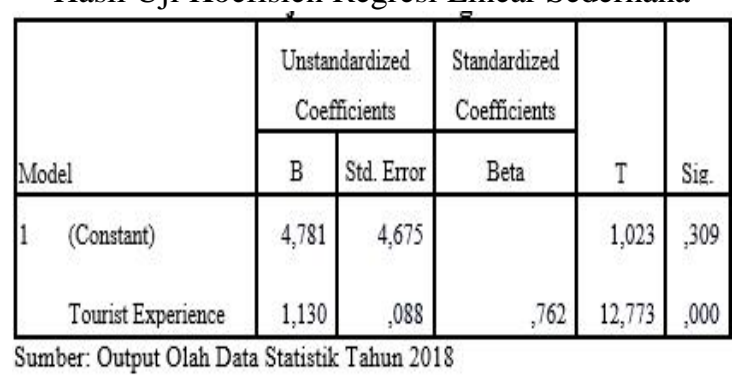

Persamaan regresi diatas dapat di jelaskan bahwa koefesien regresi variabel Tourist Experience berpengaruh positif terhadap Behavioral Intention. Persamaan regresi sederhana untuk membangun nilai behavioral intention melalui tourist experience dapat dinyatakan sebagai berikut: $\mathrm{Y}=\mathrm{a}+\mathrm{bX}, \mathrm{Y}=4,781+1,130 \mathrm{X}$

Keterangan:

$\mathrm{Y}=$ Behavioral Intention

$\mathrm{X}=$ Tourist Experience

Hasil analisis menunjukkan Koefesien regresi untuk $x$ sebesar 1,130 dan bertanda positif dengan signifikansi 0,000 . Hal ini berarti bahwa setiap peningkatan perubahan nilai Tourist Experience akan memberikan peningkatan skor sebesar 1,130.

\section{Pengujian Hipotesis}

Analisis Koefisien Determinasi $\left(R^{2}\right)$

Koefisien determinasi pada penelitian ini dapat diketahui dengan melihat nilai $R$ square pada hasil perhitungan statistik oleh software SPSS 24 for Windows seperti yang ditunjukan pada Tabel 5 berikut: 
Tabel 5

\begin{tabular}{|c|c|c|c|c|c|}
\hline \multicolumn{6}{|c|}{ Hasil Uji Koefesien Determinasi $\left(\mathrm{R}^{2}\right)$} \\
\hline \multicolumn{6}{|c|}{ Model Summary ${ }^{\mathrm{b}}$} \\
\hline & & \multirow{3}{*}{$\begin{array}{c}\mathrm{R} \\
\text { Square }\end{array}$} & \multirow{3}{*}{$\begin{array}{l}\text { Adjusted } \\
\text { R Square }\end{array}$} & \multirow{3}{*}{$\begin{array}{c}\text { Std. } \\
\text { Error of } \\
\text { the } \\
\text { Estimate }\end{array}$} & \multirow{3}{*}{$\begin{array}{l}\text { Durbin- } \\
\text { Watson }\end{array}$} \\
\hline & & & & & \\
\hline Model & $\mathrm{R}$ & & & & \\
\hline 1 &, $762^{\mathrm{a}}$ &, 580 &, 577 & 7,62512 & 2,305 \\
\hline & & onst & deravis & & \\
\hline & Dutn & Olah I & ta Stati & Telu & \\
\hline
\end{tabular}

Tabel 5, menunjukan hasil uji koefisien determinasi $\left(\mathrm{R}^{2}\right)$. Dari tabel tersebut, dapat dilihat bahwa nilai $\mathrm{R}$ square $=0,580$. Maka dapat diindikasikan bahwa tourist experience berpengaruh terhadap behavioral intention sebesar $58 \%$, sedangkan sisanya, yaitu $42 \%$ dipengaruhi oleh variabel-variabel lain yang tidak diteliti dalam penelitian ini.

\section{Uji Parsial (Uji t)}

Uji parsial pada penelitian ini dapat diketahui dengan melihat nilai $\mathrm{T}$ pada hasil perhitungan statistik oleh software SPSS 24 for Windows seperti yang ditunjukan pada Tabel 6 berikut:

Tabel 6

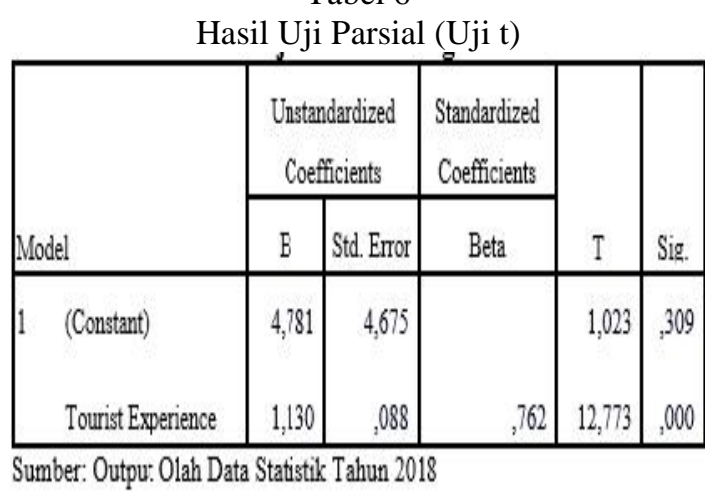

Melihat Tabel 6 hasil uji t di atas, pengaruh Tourist experience terhadap behavioral intention secara parsial menghasilkan nilai $\mathrm{t}$ hitung $=12,773$ dan signifikansi hitung $=$ 0,000 . Dengan menggunakan signifikansi $\alpha$ $(0,05)$ dan derajat kebebasan (df) n-k-1 atau 120-1-1 = 118 ( $\mathrm{n}=$ jumlah responden dan $\mathrm{k}=$ jumlah variabel independen), diperoleh $\mathrm{t}$ table sebesar 1,980. Artinya, t hitung lebih besar dari t tabel dan signifikansi hitung lebih kecil dari signifikansi $\alpha$. Artinya, semakin tinggi nilai variabel tourist experience maka semakin tinggi pula nilai variabel behavioral intention. Dengan demikian, $\mathrm{H}_{0}$ ditolak dan $\mathrm{H}_{\mathrm{a}}$ diterima dengan keterangan sebagai berikut:

$\mathrm{H}_{0}$ : $\rho \mathrm{yx}=0$ Tourist experience tidak berpengaruh terhadap behavioral intention secara parsial.

$\begin{array}{lll}\mathrm{H}_{\mathrm{a}} \text { : } \rho \mathrm{x} \quad \neq 0 & \text { Tourist } & \text { Experience } \\ \text { berpengaruh } & \text { terhadap } & \text { behavioral } \\ \text { intention secara parsial. } & \end{array}$

\section{PEMBAHASAN}

Berkembangnya industri pariwisata saat ini khususnya di Kabupaten Bandung Barat menimbulkan persaingan yang cukup kompetitif, sehingga menuntut destinasi pariwisata untuk dapat meningkatkan kreasi dan inovasi untuk meningkatkan kunjungan wisatawan.

Tourist experience di Floating Market Lembang merupakan aspek yang sangat penting dalam mencapai keberhasilan destinasi wisata karena pengalaman wisatawan yang positif dapat menimbulkan minat berperilaku dari wisatawan itu sendiri ke destinasi wisata tersebut seperti berkunjung ulang ataupun mengajak orang lain untuk datang ke destinasi wisata tersebut dan menjadi keuntungan tersendiri bagi pihak destinasi wisata. Hal ini selaras dengan pendapat Sharma \& Chaubey, (2014) mengatakan "The customer experience has emerged as the single most important aspect in achieving success for companies across all industries". Bahwa pengalaman pelanggan telah nampak sebagai aspek yang paling penting dalam mencapai keberhasilan perusahaan di semua industri.

\section{Tourist Experience}

Tourist Experience dalam penelitian ini terdapat lima dimensi yaitu: kenyamanan (comfort), kesenangan (hedonic), pengalaman berbeda (novelty), keamanan (safety), dan keindahan (beauty) (Rageh et al., 2013). Dimensi kenyamanan (comfort) mengarah pada basic aminities yang destinasi sediakan untuk memastikan kenyamanan dan juga menciptakan relaksasi kepada 
pengunjung diantaranya iklim/cuaca yang sejuk, fasiltas umum yang bersih dan memadai dan aktifitas wisata pengunjung yang mendukung. Penilaian pengunjung terhadap dimensi tourist experince yaitu kenyamanan (comfort) mendapatkan nilai yang sangat baik atau dalam kategori sangat tinggi.

Hedonic, melambangkan semangat, kenikmatan dan mudah dikenang, yaitu perasaan senang, semangat dan kenangan yang didapatkan oleh pengunjung selama berkunjung di Floating Market Lembang. Pengunjung dapat merasakan hal tersebut karena Floating Market Lembang menyediakan pemandangan alam, dipadukan dengan beragam aktifitas wisata yang dapat dilakukan oleh pengunjung. Berdasarkan hasil analisis deskriptif pengunjung Floating Market Lembang memberikan penilaian yang baik atau dalam kategori tinggi.

Novelty, komentar mengenai pengalaman dan perubahan dari rutinitas pengunjung mengenai destinasi wisata yang dikunjungi. Berdasarkan hasil analisis deskriptif pengunjung Floating Market Lembang memberikan penilaian yang baik atau dalam kategori tinggi.

Safety, keamanan bagi wisatawan perlu diperhatikan oleh pihak pengelola destinasi wisata agar pengunjung dapat beriwisata dengan nyaman tanpa terjadi hal-hal yang tidak diinginkan terkait keamanan. Berdasarkan hasil analisis deskriptif, pengunjung Floating Market Lembang merasa aman saat berkunjung ke sana dan memberikan penilaian baik atau dalam kategori tinggi.

Beauty, keindahan yang akan menciptakan perasaan yang penuh, kesenanganm berkurangnya kecemasan, kekaguman, kegembiraan, semangat, optimisme, dan kepuasan pengunjung atas pelayanan yang diberikan oleh destinasi wisata. Pengunjung merasakan keindahan dan keunikan yang disajikan oleh Floating Market Lembang, dan berdasarkan hasil analisis deskriptif pengunjung memberikan penilaian yang sangat baik atau dalam kategori sangat tinggi.
Secara keseluruhan tourist experience mendapatkan penilaian yang baik dari pengujung Floating Market Lembang atau dalam kategori tinggi. Penilaian ini menyatakan bahwa pengunjung merasa nyaman, senang, aman, memiliki pengalaman baru dan merasakan keindahan daya tarik dari Floating Market Lembang.

\section{Behavioral Intention}

Behavioral intention merupakan kecenderungan perilaku wisatawan untuk berkunjung kembali dan merekomendasikan akibat dari interaksi wisatawan dengan suatu destinasi. Behavioral intention wisatawan sangat penting bagi destinasi wisata, karena pemahaman niat wisatawan dari kunjungan ulang dan word of mouth setelah kunjungan mereka dapat membantu meramalkan apakah target wisatawan akan menjadi wisatawan jangka panjang (pelanggan) dan membawa keuntungan untuk destinasi wisata (Shen et al., 2014:514).

Behavioral intention pada penelitian ini terdapat dua dimensi yaitu: revisit intention dan recommendation intention (Liu, Hong, \& Li, 2013:73). Tingkat keinginan untuk berkunjung kembali (revisit intention) ke Floating Market Lembang berdasarkan hasil analisis deskriptif, pengunjung memberikan penilaian yang baik atau dalam kategori tinggi karena Pengunjung merasakan kenyamanan, kesenangan, bersemangat, keamanan, keindahan dan keunikan serta memiliki kenangan dan pengalaman baru setelah berkunjung ke Floating Market Lembang.

Tingkat kesediaan untuk merekomendasikan (recommendation intention) Floating Market Lembang kepada orang lain berdasarkan analisis deskriptif, pengunjung memberikan penilaian yang baik atau dalam kategori tinggi karena Pengunjung telah merasakan kenyamanan, kesenangan, bersemangat, keamanan, keindahan dan keunikan serta memiliki kenangan dan pengalaman baru selama berkunjung ke Floating Market Lembang dan atas dasar tersebut pengunjung ingin merekomendasikan Floating Market Lembang kepada orang lain. 
Secara keseluruhan behavioral intention mendapatkan penilaian yang baik dari pengunjung Floating Market Lembang atau dalam kategori tinggi. Penilaian ini menyatakan bahwa pengunjung telah merasakan kenyamanan, kesenangan, bersemangat, keamanan, keindahan dan keunikan serta memiliki kenangan dan pengalaman baru selama berkunjung ke Floating Market Lembang dan atas dasar tersebut pengunjung berkeinginan untuk berkunjung kembali dan merekomendasikan Floating Market Lembang kepada orang lain.

\section{Membangun Nilai Behavioral Intention Melalui Tourist Experience}

Keberhasilan Behavioral Intention sangat ditentukan oleh keberhasilan Tourist Experience. Hal ini selaras dengan pendapat yang disampaikan Chang et al., (2014) yang menyatakan bahwa sangat penting bagi pengelola atraksi wisata untuk lebih memperhatikan dalam memahami pengalaman wisatawan saat mereka berwisata ke tempat wisata tersebut. Ketika pengalaman wisatawan baik, maka minat berwisata ulang semakin mungkin terjadi. Hal ini dikuatkan oleh pandangan Cole \& Illum (2006), yang menjelaskan bahwa aspek psikologis wisatawan sangat berkaitan erat dengan manfaat yang mereka terima, sehingga berpengaruh terhadap perilaku berwisata mereka di masa depan. Tingginya keberhasilan behavioral intention yang sangat ditentukan melalui tourist experience dalam penelitian ini, menguatkan hasil penelitian sebelumnya yang menjelaskan bahwa tourist experience di Gunung Galunggung berada pada kategori tinggi dan behavioral intention berada pada kategori cukup tinggi, behavioral intention dipengaruhi oleh tourist experinece sebesar 47,4\% (Balqis, 2016).

Tahapan proses membangun behavioral intention menuju peningkatan tourist experience bahwa Floating Market Lembang sebagai destinasi pariwisata dapat melakukan identifikasi terhadap aspek-aspek penting dalam membangun pariwisata mengacu pada temuan hasil penelitian sebagai persepsi pengunjung yang terjadi dalam bentuk belum meratanya tingkat kepuasan pengunjung sampai pada tingkat sangat baik. Identifikasi hasil penelitian ini dapat digambarkan pada aspek kenyamanan yang masih sebatas baik, tingkat kesenangan yang juga belum tercapai pada titik paling tinggi, sehingga berdampak pada tingkat pengalaman yang biasa, dengan tingkat keamanan yang juga biasa dan keindahan alam maupun pemandangan yang biasa. Identifikasi ini merupakan bagian dari upaya pihak pengelola sebagai wujud adanya keinginan terhadap perubahan kea rah yang lebih baik, dan juga proses persiapan menuju implementasi peningkatan behavioural intention. Tingginya tingkat harapan yang digambarkan dalam persepsi pengunjung ini terwujud pada tingginya tingkat keterkaitan antara tourist experience dengan behavioural intention. Artinya bahwa implementasi peningkatan lima aspek pendukung behavioural intention tidak bisa ditunda lagi, karena dampaknya akan secara langsung terjadi pada penurunan kunjungan ulang wisatawan bahkan rendahnya keinginan wisatawan untuk memberikan rekomendasi kepada calon pengunjung lainnya. Atas dasar penjelasan ini, maka dapat disampaikan bahwa membangun behavioural intention yang diwujudkan melalui peningkatan kenyamanan wisatawan saat berkunjung, peningkatan kesenangan pengunjung, penumbuhan pengalaman baru, dan peningkatan keamanan wisatawan selama berada di tempat wisata serta terpeliharanhya keindahan lingkungan alam dan lingkungan sekitar di destinasi wisata akan menjadi faktor penentu keberhasilan yang digambarkan melalui tumbuhnya keinginan wisatawan dalam melakukan kunjungan ulang dan juga tumbuhnya keinginan wisatawan untuk memberikan rekomendasi kepada orang lain dalam melakukan kunjungan ke destinasi. Semakin tinggi tingkat keberhasilan pihak pengelola dalam membangun peningkatan dan penumbuhan kenyamanan, kesenangan, pengalaman baru, keamanan dan keindahan wisatawa maka akan tumbuh sikap dan perilaku wisatawan dalam melakukan kunjungan ulang dan 
perilaku memberikan rekomendasi tempat kunjungan kepada orang lain. Atau sebaliknya.

\section{KESIMPULAN}

Tourist experience di Floating Market Lembang tergambar dari pengunjung yang merasakan kenyamanan atas wahana yang tersedia, kesenangan atas kunjungan terhadap beberapa wahana serta fasilitas yang ada, semangat kunjungan untuk melihat fasilitas dan produk wisata, keamanan yang diberikan oleh pihak pengelola selama kunjungan, keindahan dan keunikan atas fasilitas dan keadaan alam yang ada, sehingga akhirnya pengunjung memiliki kenangan dan pengalaman yang baru yang memberikan kesan positif selama berkunjung ke Floating Market Lembang.

Behavioral intention di Floating Market Lembang tergambar dari tingginya keinginan pengunjung untuk melakukan kunjungan ulang atas kenyamanan yang dirasakan selama melakukan kunjungan, kesenangan setelah melakukan kunjungan, semangat yang tinggi untuk melakukan kunjungan, keamanan yang dirasakan, keindahan dan keunikan serta memiliki kenangan dan pengalaman baru selama berkunjung ke Floating Market Lembang.

Tourist experience penting dilakukan oleh Floating Market Lembang jika ingin memperoleh behavioral intention yang tinggi, demikian juga jika Floating Market Lembang ingin meningkatkan behavioral intention terhadap jasa yang diberikan maka Floating Market Lembang harus benar-benar memperhatikan dan meningkatkan tourist experience dari wisatawan yang berkunjung. Semakin tinggi tingkat keberhasilan Floating Market Lembang dapat membangun tourist experience wisatawannya maka semakin tinggi pula peluang bagi Floating Market Lembang untuk mendapatkan peningkatan kunjungan ulang wisatawannya atau sebaliknya,

Berdasarkan kesimpulan yang diperoleh dalam penelitian ini, saran-saran yang dapat diberikan untuk Floating Market Lembang adalah sebagai berikut:

Tourist experience merupakan salah satu strategi dalam upaya meningkatkan dan mempertahankan behavioral intention dalam sebuah perusahaan khususnya industri pariwisata. Berdasarkan penelitian ini, diketahui bahwa pada sub variabel novelty mendapat tanggapan lebih rendah dibandingkan dengan sub variabel lainnya pada variabel tourist experience. Oleh karena itu diharapkan pengelola dapat menciptakan terobosan baru dalam pengembangan wisata dan meningkatkan kualitas pelayanan seperti penanaman pohon rindang di sekitar area parkir, dapat ditambah untuk penyediaan welcome drink minuman tradisonal Jawa Barat dan jenis makanan yang disediakan lebih bervariasi, serta lebih meningkatkan budaya lokal di Floating Market Lembang

Revisit intenton pada variabel behavioral intention mendapatkan nilai terendah dibandingkan dengan sub variabel lain. Hal ini terjadi karena sebagian pengunjung merasakan kurang puas atas kenyamanan, kesenangan, keamanan, keindahan dan pengalaman yang diperoleh selama berkunjung ke Floating Market Lembang. Berdasarkan hal tersebut peneliti merekomendasikan agar Floating Market Lembang dapat melakukan evaluasi kerja terkait aspek yang menjadi ketidakpuasan pengunjung dalam berkunjung ke Floating Market Lembang seperti meningkatkan pelayanan wisata dan menambah fasilitas wahana baru berdasarkan terobosan baru.

Manajemen Floating Market Lembang diharapkan terus berupaya untuk meningkatkan tourist experience dengan tujuan dapat meningkatkan dan mempertahankan behavioral intention.

\section{REFERENSI}

Balqis, N. 2016. Pengaruh Tourist Experience Terhadap Behavioral Intention (Survey Terhadap Wisatawan Nusantara yang Berkunjung ke Gunung Galunggung. Universitas Pendidikan Indoensia. 
Chang, L. L., Backman, K. F., \& Huang, Y. C. 2014. Creative tourism: a preliminary examination of creative tourists' motivation, experience, perceived value and revisit intention. International Journal of Culture, Tourism, and Hospitality Research, 8(4), 401-419. https://doi.org/10.1108/IJCTHR-042014-0032

Chen, C. F., \& Tsai, D. C. 2007. How destination image and evaluative factors affect behavioral intentions? Tourism Management, 28(4), 1115-1122. https://doi.org/10.1016/j.tourman.2006. 07.007

Cole, S. T., \& Illum, S. F. 2006. Examining the mediating role of festival visitors' satisfaction in the relationship between service quality and behavioral intentions. Journal of Vacation Marketing, 12(2), 160-173. https://doi.org/10.1177/1356766706062 156

De Nisco, A., Mainolfi, G., Marino, V., \& Napolitano, M. R. 2015. Tourism satisfaction effect on general country image, destination image, and post-visit intentions. Journal of Vacation Marketing, 21(4), 305-317. https://doi.org/10.1177/1356766715577 502

Kuruuzum, A., \& Koksal, C. D. 2010. The Impact of Service Quality on Behavioral Intention in Hospitality Industry. International Journal of Business Adn Management Studies, 2(1), 9-15. https://doi.org/10.22412/1995-042x-11$2-8$

Liu, C.-H., Hong, C.-Y., \& Li, J.-F. 2013. the Determinants of Ecotourism Behavioral Intentions. Global Journal of Business Research, 7(4), 71-84. Retrieved from http://search.proquest.com/docview/135 0301582? accountid=79789
Lovelock, C. H., \& Wirtz, J. 2010. Services Marketing - People, Technology, Strategy. In Harvard Business Review (pp. 329-331).

Othman, Z., Zahari, M. S. M., \& Radzi, S. M. 2013. Customer Behavioral Intention: Influence of Service Delivery Failures and Service Recovery in Malay Restaurants. Procedia - Social and Behavioral Sciences, 105, 115-121. https://doi.org/10.1016/j.sbspro.2013.11 .013

Rageh, A., Melewar, T. C., \& Woodside, A. 2013. Using netnography research method to reveal the underlying dimensions of the customer/tourist experience. Qualitative Market Research: An International Journal, 16(2), 126-149. https://doi.org/10.1108/1352275131131 7558

Ramukumba, T. 2018. Tourists revisit intentions based on purpose of visit and preference of the destination. A case study of Tsitsikamma National Park. African Journal of Hospitality, Tourism and Leisure, 7(1), 1-10.

Sharma, M., \& Chaubey, D. S. 2014. An Empirical Study of Customer Experience and its Relationship with Customer Satisfaction towards the Services of Banking Sector. Journal of Marketing \& Communication, 9(3), 1827. Retrieved from http://search.ebscohost.com/login.aspx? direct $=$ true $\& \mathrm{db}=\mathrm{bsh} \& \mathrm{AN}=95858839 \& \mathrm{~s}$ ite $=$ ehost-live

Shen, H., Fan, S., Zhan, J., \& Zhao, J. 2014. A Study of the Perceived Value and Behavioral Intentions of Chinese Marine Cruise Tourists. Tourism, Leisure and Global Change, 1(April), 96-117.

Sugiyono. 2014. Metode Penelitian 
Pendidikan Pendekatan Kuantitatif,

Kualitatif dan $R \& D$.

https://doi.org/10.1007/s13398-014-

0173-7.2

Syarifuddin, D. 2013. Tourism Destination Service Quality to Tourist Satisfaction.

Majalah Ilmiah Kopertis Wilayah IV, 113.

Syarifuddin, D. 2017. Memaknai Kuliner Lokal Sebagai Daya Tarik Wisaya. Abdimas, 4-8.

Syarifuddin, D. 2019. Nilai Citra Kota dari Sudut Pandang Wisatawan (Studi Tentang Citra Kota Bandung Dampaknya Terhadap Kunjungan Ulang). Journal of Indonesian Tourism, Hospitality and Recreation, 1(2). https://doi.org/10.17509/jithor.v1i2.137
61

Tang, J., \& Qiu, C. 2015. Research on Motivation, Experience, Satisfaction and Behavioral Intention of Museum Tourism - A Case of Macau Museum. In G. Zeng (Ed.), Tourism and Hospitality Development Between China and EU (pp. 137-156). https://doi.org/10.1007/978-3-64235910-1

Walter, U., Edvardsson, B., \& Ostrom, A. 2010. Sosial Interaxtions as Drivers of Customers' Service Experience. The 11th International Research Seminar in Service Management Social Interactions as Drivers of Customers ' Service Experiences by Ute WALTER, Bo EDVARDSSON , Åsa ÖSTRÖM Social Interactions as Drivers of Cust, 1-21. 